\title{
RESEARCH NOTES AND APPLICATION REPORTS NITROGEN AND FLUORINE DATING OF MOUNDVILLE SKELETAL SAMPLES
}

\author{
A. HADDY \\ Museum of Anthropology, University of Michigan, Ann Arbor, Michigan, U.S.A. \\ and A. HANSON \\ Brookhaven National Laboratory, Upton, New York 11973, U.S.A.
}

\section{INTRODUCTION}

A large group of human bones were excavated during the 1930's from the Moundville archaeological site in Alabama. If a chronology could be assigned to them, the bones might provide a guide to the changes which took place as Moundville flourished, since pottery and other objects were often buried with the individuals. A recent pottery classification based on style suggests three major time periods at Moundville (Steponaitis, 1978):

Moundville I A.D. 1100-1250

Moundville II A.D. $1250-1400$

Moundville III A.D. 1400-1550

Since all of the bones were treated upon unearthing with the preservative Alvar, the trade name for polyvinyl acetate, absolute dating by carbon-14 is not possible. In this preliminary study nineteen bone samples from fifteen individuals were analyzed for nitrogen and fluorine, since the concentrations of these elements will provide relative dates for the bones.

Nitrogen dating is based on the fact that buried bones and teeth lose nitrogen over time. Fresh human bone contains about 5\% nitrogen (Ortner et al. 1972), mostly in the form of the protein collagen. As bone decomposes, collagen breaks down into its constituent amino acids which then leach out of the bone. Thus the nitrogen concentration decreases with time. The rate of nitrogen loss is dependent on environmental factors such as temperature, soil $\mathrm{pH}$, ground water content and collagen-degrading micro-organisms (Ortner et al. 1972, Garlick, 1969, Von Endt 1979).

One of the processes involved in fossilization is the accumulation of the fluoride ions in bone (Hoskins et al. 1955). Fluoride ions replace hydroxide ions in the mineral hydroxyapatite $\mathrm{Ca}_{10}\left(\mathrm{PO}_{4}\right)_{6}(\mathrm{OH})_{2}$. This takes place as a result of the higher molecular stability of fluoroapatite over hydroxyapatite (Hagen 1973, Tse et al. 1973). Like the loss of nitrogen, the rate of fluorine accumulation is dependent on environmental factors, such as temperature, soil $\mathrm{pH}$, ground water content and soil fluorine content (Hagen 1973). In order to assume that the bones were exposed to the same environmental factors, which is a necessity for both nitrogen and fluorine dating methods, samples must be from the same vicinity.

Another assumption involved in both of these dating methods is the comparability of bone types. Since fluorine diffuses into the bone through the surface, a concentration gradient is created. Thus thinner bones with a higher surface area to volume ratio will have a higher average fluorine content. In the case of nitrogen, thin porous bones probably lose nitrogen faster than more solid bones, owing to the higher water permeability. Therefore if the dimensions 
of the bone influences the concentrations of nitrogen and fluorine, this variable must be kept constant.

The final assumption is that upon burial, the nitrogen and fluorine concentrations were constant for all individuals. This is a valid assumption for nitrogen since only children have bone nitrogen concentrations other than $5 \%$ and there were no children in this study. However, this is not a particularly good assumption for fluorine since adults are known to accumulate this element throughout most of their lifetimes at a rate depending on dietary fluorine (Underwood 1977).

\section{SAMPLE PREPARATION}

Ideally, analyses should be carried out on the same type of bone from each individual. Unfortunately, there was a limited selection available for this study, so bone types which were most abundant were chosen. Ulnas and tibias were the most common bones analyzed, but some odd bones such as clavicles and ribs were also analyzed. No attempt was made to remove the Alvar for fear of removing either nitrogen or fluorine, or contaminating the nitrogen assay. Each sample was measured for thickness and then ground with a porcelain mortar and pestal to a fine powder. For fluorine analyses, the ground samples were pressed into aluminum planchets at $1000 \mathrm{~N} / \mathrm{cm}^{2}$, forming a disk $2.6 \mathrm{~cm}$ in diameter and $2 \mathrm{~mm}$ thick.

\section{ANALYTICAL METHODS}

Nitrogen analyses were carried out using the micro-Kjeldahl technique as described by Ortner and Von Endt (Ortner et al. 1972). In this method, a small sample of ground bone weighing approximately $10 \mathrm{mg}$ is digested in boiling sulfuric acid solution. This converts all organic nitrogen into ammonium $\left(\mathrm{NH}_{4}^{+}\right)$form. The digested sample is then neutralized and analyzed using a Nessler's reagent. This reagent forms a yellow colored complex when combined with ammonia. Nitrogen is quantified spectrophotometrically by comparison with an ammonium chloride standard, in this case using a McPherson double beam spectrophotometer, model EU-700.

Fluorine analyses were done at Brookhaven National Laboratory with a recently developed technique, proton inelastic scattering (Shroy et al. 1978), using the reaction

$$
{ }^{19} \mathrm{~F}\left(\mathrm{p}, \mathrm{p}^{\prime}\right){ }^{19} \mathrm{~F}^{*}
$$

The samples were bombarded with a $3.4 \mathrm{MeV}$ proton beam from the BNL $3.5 \mathrm{MV}$ Van de Graaff accelerator. In this method inelastic scattering of the protons leaves the fluorine nuclei in an excited state. These atoms then decay emitting $110 \mathrm{kEV}$ and $197 \mathrm{keV}$ gamma rays at a rate dependent on the fluorine concentration and proton current. In this study, the gamma rays were counted at 90 degrees from the beam with a teflon free $\mathrm{Ge}(\mathrm{Li})$ detector. The two-mm thickness of the samples was greater than the range of the protons. Data were analyzed with a Nuclear Data 6660 analyzer and minicomputer. The glass sample holder was lined with mylar to reduce the number of gamma rays from fluorine contamination within the system. The contamination gamma ray yield was more than a factor of one thousand less than the yield from the samples. Absolute fluorine calibration was performed by comparison with National Bureau of Standards certified phosphate rock.

Nuclear reaction methods for fluorine analysis (which also includes the ${ }^{19} \mathrm{~F}(\mathrm{p}, \alpha){ }^{16} 0^{*}$ 
reaction) are extremely sensitive techniques with a sensitivity less than one ppm. They have several advantages over traditional wet chemical techniques. First, the sample is not destroyed. Second, fluorine can be detected in any chemical form. Third, by varying the energy of the proton beam, fluorine can be measured at specific depths within the sample (a depth profile). A depth profile of fluorine concentration may be more indicative of geological age than the average fluorine concentration. Although depth profiles were not attempted in this study, they have been measured for a set of chipped lithic samples (Taylor 1975). A disadvantage of nuclear reaction methods is that the calculation of absolute fluorine concentration is based on knowledge of the overall composition and density of the sample and the standard. Fortunately, we are interested in relative amounts of fluorine so that this problem is not of great concern.

\section{RESULTS}

Results of nitrogen and fluorine analyses of all (nineteen) samples have been compiled and are presented in table 1 and figure 1 . The samples were excavated from gravelots in the vicinity of the mounds listed in table 1. (The sample identification numbers and their relationships to the mounds are on file at the mound state Monument in Alabama (Mound State Files 1979).) For nitrogen, two to three analyses were done. For fluorine, one to four analyses were done. The

Table 1 Nitrogen and fluorine concentrations

\begin{tabular}{|c|c|c|}
\hline Sample & Nitrogen $(\%)$ & Fluorine ( $\mathrm{ppm}$ ) \\
\hline \multicolumn{3}{|l|}{ Mound D } \\
\hline $1423 S$ ulna & $2.47 \pm 0.04$ & $493 \pm 10$ \\
\hline $1496 \mathrm{~S}$ metatarsal & - & $226 \pm 2$ \\
\hline $1515 S$ tibia & $1.39 \pm 0.05$ & $494 \pm 24$ \\
\hline metatarsal & - & $548 \pm 23$ \\
\hline 1539S ulna & $2.86 \pm 0.01$ & $311 \pm 8$ \\
\hline 1563S ulna & $2.03 \pm 0.01$ & $186 \pm 4$ \\
\hline \multicolumn{3}{|l|}{ Mound $E$} \\
\hline $1183 \mathrm{E}$ clavicle & - & $272 \pm 3$ \\
\hline uina & - & $240 \pm 17$ \\
\hline $1587 \mathrm{~N}$ ilium & - & $669 \pm 14$ \\
\hline $1647 \mathrm{~N}$ tibia & $1.87 \pm 0.01$ & $166 \pm 6$ \\
\hline ulna & $1.94 \pm 0.23$ & - \\
\hline $1648 \mathrm{~N}$ tibia & $1.07 \pm 0.07$ & $775 \pm 26$ \\
\hline \multicolumn{3}{|l|}{ Mound $G$} \\
\hline $1788 \mathrm{SW}$ femur & $1.78 \pm 0.11$ & $324 \pm 4$ \\
\hline 1800SW ulna & $2.10 \pm 0.03$ & $217 \pm 4$ \\
\hline \multicolumn{3}{|l|}{ Mound I } \\
\hline 839 E clavicle & $2.85 \pm 0.01$ & $262 \pm 5$ \\
\hline \multicolumn{3}{|l|}{ Mound $P$} \\
\hline 2417 W ulna & $1.59 \pm 0.08$ & $496 \pm 4$ \\
\hline rib & - & $608 \pm 12$ \\
\hline \multicolumn{3}{|l|}{ Mound $R$} \\
\hline 1065W tibia & $1.93 \pm 0.01$ & $432 \pm 2$ \\
\hline \multicolumn{3}{|l|}{ Mound $w$} \\
\hline $1840 \mathrm{~N}$ tibia & $1.52 \pm 0.01$ & - \\
\hline
\end{tabular}




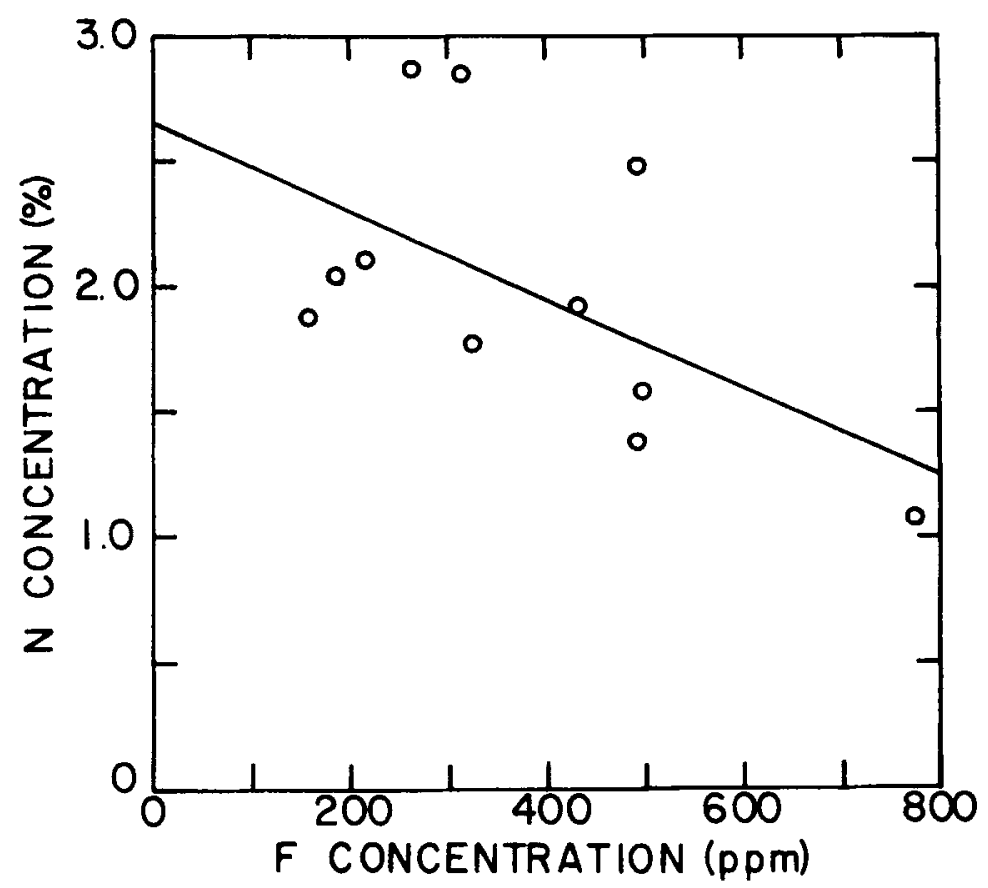

Figure 1 Comparison of the nitrogen and fluorine contents of the eleven samples analyzed for both elements.

standard deviations for repeat nitrogen and fluorine analyses were usually less than $4 \%$. When powdering the bone, the Alvar had a tendency to remain in flakes for samples in which it was particularly thick. This caused inconsistencies that resulted in higher statistical errors for those particular samples.

As mentioned earlier, bones are expected to have the highest local concentration of fluorine at the surface and we were able to show such a difference for one of the bones. The thickest sample, femur $1788 \mathrm{SW}$, was chosen and a separate sample was prepared from the outer mm or so of bone. Even though this part of the bone had a much higher amount of Alvar, which would dilute the fluorine, its fluorine content was over twice that of the whole sample.

If there is more fluorine at the surface of bones, then thinner bones may be expected to have a higher average amount of fluorine. A comparison of fluorine was made between different bones from the same individual, and this sort of trend may be suggested by the data. The rib $(0.13 \mathrm{~cm}$ thick) of $2417 \mathrm{~W}$ had about $23 \%$ more fluorine than the ulna $(0.24 \mathrm{~cm}$ thick $)$, and the metatarsal $(0.14 \mathrm{~cm}$ thick) of $1515 \mathrm{~S}$ had about $11 \%$ more fluorine than the tibia $(0.53 \mathrm{~cm}$ thick). The clavicle and ulna from $1183 \mathrm{E}$ are about the same thickness but there is a $13 \%$ difference in their fluorine concentrations. This particular ulna had been treated with some organic solvent which was probably used to remove the Alvar; it may have removed some fluorine as well.

It is not evident that a diffusion gradient exists for nitrogen. The nitrogen content of the tibia $(0.51 \mathrm{~cm}$ thick $)$ and ulna $(0.16 \mathrm{~cm}$ thick $)$ of $1647 \mathrm{~N}$ were both approximately $1.9 \%$ nitrogen, yet they have very different thicknesses (which indicates that ulnas and tibias are suitable for comparison). 
Table 2 Rank correlation between nitrogen and fluorine analyses $(1=$ oldest, $11=$ newest )

\begin{tabular}{|c|c|c|c|c|}
\hline Sample & $\% \mathrm{~N}$ Rank & F Rank & $d$ & $d^{2}$ \\
\hline 1648 tibia & 1 & 1 & 0 & 0 \\
\hline 1515 tibia & 2 & 3 & 1 & 1 \\
\hline 2417 ulna & 3 & 2 & 1 & 1 \\
\hline 1788 femur & 4 & 6 & 2 & 4 \\
\hline 1647 tibia & 5 & 11 & 6 & 36 \\
\hline 1065 tibia & 6 & 5 & 1 & 1 \\
\hline 1563 ulna & 7 & 10 & 3 & 9 \\
\hline 1800 ulna & 8 & 9 & 1 & 1 \\
\hline 1423 ulna & 9 & 4 & 5 & 25 \\
\hline 839 clavicle & 10 & 8 & 2 & 4 \\
\hline \multirow[t]{2}{*}{1539 ulna } & 11 & 7 & 4 & 16 \\
\hline & & & & $\begin{aligned} \Sigma d^{2} & =98 \\
t & =2.0\end{aligned}$ \\
\hline
\end{tabular}

Samples from eleven of the fifteen individuals in this study were analyzed for both nitrogen and fluorine. A rank correlation between the two methods was performed for these eleven samples. The oldest bone was assigned a rank of one and the newest a rank of eleven (table 2). Using Spearman's method for rank correlation (Yule et al. 1965), the rankings were found to be statistically significant at a $96 \%$ confidence level. The nitrogen concentrations of samples $1788 \mathrm{SW}$ and $1647 \mathrm{~N}$ and samples $839 \mathrm{E}$ and $1539 \mathrm{~S}$ are close enough that the uncertainties of the analyses overlap. Likewise the fluorine content of samples $1515 \mathrm{~S}, 2417 \mathrm{~W}$ and $1423 \mathrm{~S}$ are also within each other's error limits, given in table 1. Various rearrangements of the rankings of these samples will change the confidence level quoted for the correlation, the lowest confidence level being $89 \%$.

As illustrated in table 2, tibia $1647 \mathrm{~N}$ and ulna $1423 \mathrm{~S}$ show the largest discrepancies in their relative rankings. A likely source of disagreement is the Alvar content. Although Alva does not interfere chemically in either analysis, it adds extraneous weight to the sample. Since both percentages are based on weight, extra total weight will make a sample appear older by nitrogen dating and younger by fluorine dating.

\section{DISCUSSION}

Table 3 shows data arranged by burial mounds. Possible relative ages have been assigned based on nitrogen and fluorine concentrations, with classifications ranging from early to late. Included in this table is the gravelot classification performed by Steponaitis (Steponaitis 1979) based on pottery styles. The time periods were divided into Moundville I (I), early Moundville II (eII), late Moundville II (1II), early Moundville III (eIII) and late Moundville III (1III). The relative grouping assignments, as determined by the two classification techniques, are also plotted in figure 2. Each sample has two curves plotted; the upper curve is the grouping range determined by pottery style, and the lower curve is the grouping range determined by relative dating. 
Table 3 Comparison of seriations

\begin{tabular}{|c|c|c|c|c|}
\hline Sample & $\% N$ & Fluorine & $\begin{array}{l}\text { Grouping by } \\
\text { relative dating }\end{array}$ & $\begin{array}{l}\text { Grouping by } \\
\text { pottery styles }\end{array}$ \\
\hline \multicolumn{5}{|l|}{ Mound D } \\
\hline $1423 \mathrm{~S}$ ulna & 2.47 & 493 & moderate to mod. late & 1II, 1III \\
\hline $1496 \mathrm{~S}$ metatarsal & - & 226 & late & 1II, eIII \\
\hline $\begin{array}{l}1515 \mathrm{~S} \text { tibia } \\
\text { metatarsal }\end{array}$ & $\begin{array}{c}1.39 \\
-\end{array}$ & $\begin{array}{l}494 \\
548\end{array}$ & early to moderate & eIII, 1 III \\
\hline 1539S ulna & 2.86 & 311 & mod. late to late & elII \\
\hline $\begin{array}{l}\text { 1563S ulna } \\
\text { Mound E }\end{array}$ & \multicolumn{3}{|c|}{ Mound E } & elII, 1 III \\
\hline $\begin{array}{l}1183 \mathrm{E} \text { ulna } \\
\text { clavicle }\end{array}$ & - & $\begin{array}{l}240 \\
272\end{array}$ & late & $1 \mathrm{III}$ \\
\hline $1587 \mathrm{~W}$ ilium & - & 669 & early & 1II, eIII \\
\hline $\begin{array}{r}1647 N \text { tibia } \\
\text { ulna }\end{array}$ & $\begin{array}{l}1.87 \\
1.94\end{array}$ & $\begin{array}{c}166 \\
-\end{array}$ & moderate to late & 1II, eIII \\
\hline \multicolumn{4}{|l|}{ Mound $G$} & 1II, eIII \\
\hline $1788 \mathrm{SW}$ femur & 1.78 & 324 & mod. early to mod. late & ellI \\
\hline \multicolumn{4}{|l|}{ Mound I } & eIII, 1III \\
\hline $\begin{array}{l}839 \mathrm{E} \text { clavicle } \\
\text { Mound } P\end{array}$ & 2.85 & 262 & late & I \\
\hline $\begin{array}{c}2417 \text { W ulna } \\
\text { rib }\end{array}$ & $\begin{array}{c}1.59 \\
--\end{array}$ & $\begin{array}{l}496 \\
608\end{array}$ & mod. early to moderate & 1111 \\
\hline Mound $R$ & & & & \\
\hline $\begin{array}{l}1065 W \text { tibia } \\
\text { Mound } W\end{array}$ & 1.93 & 432 & moderate & eIII, 1III \\
\hline $1840 \mathrm{~N}$ tibia & 1.52 & - & mod. early & eIII, 1III \\
\hline
\end{tabular}

The bone samples from the vicinity of Mound D fall mainly in a moderate to late time period by relative dating. Pottery analysis places them all in a period between late Moundville II and late Moundville III. The individuals from Mound $\mathrm{E}$ show a much greater age separation. $1647 \mathrm{~N}$ and $1648 \mathrm{~N}$ were found side by side and by pottery analysis have been classified together as late Moundville II or early Moundville III. By relative dating $1648 \mathrm{~N}$ is by far the oldest sample analyzed. On the other hand, $1647 \mathrm{~N}$ is a much later sample. According to this data, this gravelot is an early one which was reopened for burial.

Only one sample analyzed, $839 \mathrm{E}$, was classified as Moundville I by pottery analysis. There is no doubt that it is the earliest sample ceramically, but by relative dating it is one of the most recent samples. It has $2.85 \%$ nitrogen and $262 \mathrm{ppm}$ fluorine. It is likely that the pottery and the individual were not buried together, which means that the sample cannot be taken as representative of Moundville I. It is not certain at this time what concentrations of nitrogen and fluorine are to be expected in a Moundville I sample.

Besides the fact that the two dating methods crosschecked, the most notable result from the data is the broad ranges of the nitrogen and fluorine concentrations. The nitrogen content changes almost threefold from $1.07 \%$ to $2.86 \%$ and the fluorine content changes almost fivefold 


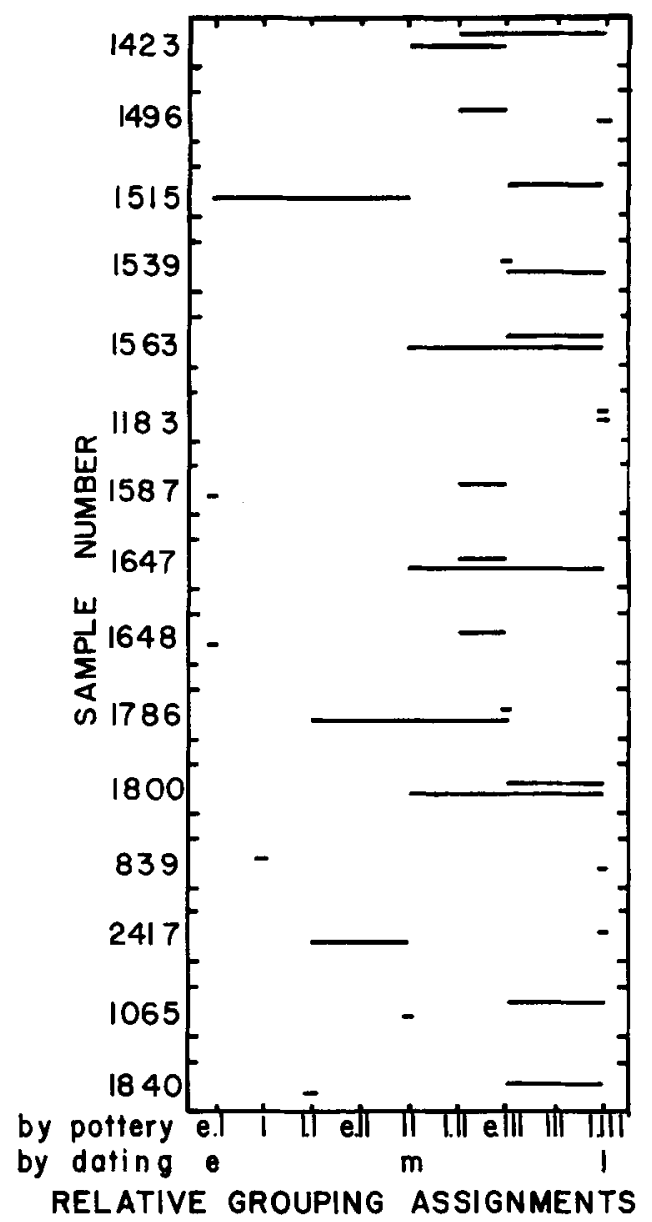

Figure 2 Relative grouping assignments as determined by pottery analysis and by relative dating. Each sample has two curves; the upper curve is the grouping range determined by pottery analysis, and the lower curve is the grouping range determined by relative dating.

from 166 to $775 \mathrm{ppm}$. This shows an excellent sensitivity of the methods to the time span over which these burials took place.

We can assume that all of the bones started with the same amount of nitrogen at the time of burial, 5\%. It has been shown by investigators such as Ortner and Von Endt that the amount of nitrogen in buried bone decreases exponentially with time (Ortner et al. 1972). Therefore the rate of nitrogen loss decreases with time. Following this line of reasoning, a bone with $1 \%$ nitrogen would be more than twice as old as a bone with $3 \%$ nitrogen. If this is true, it means that the oldest bone in this study, $1648 \mathrm{~N}$, is probably at least twice the age of the newest, possibly putting it in the Moundville I period.

\section{CONCLUSIONS}

This study shows that nitrogen and fluorine dating give the same general chronological trends for the Moundville bones. There are still problems to be worked out, such as Alvar contamination and the comparability of bones, but in general results are good. Relative dating can 
therefore be a reliable aid to anthropological studies, particularly as a screening for samples to be carbon-14 dated. Fluorine analysis by proton beams proves to be useful as a new, simple method and will provide some very interesting possibilities if fluorine depth profiles could be obtained. This preliminary study raises questions about the chronology of some of the Moundville burials; they may be answered by relative dating of a much larger group of bones.

\section{ACKNOWLEDGMENTS}

This research is supported in part by the U.S. Department of energy, Division of Basic Energy Sciences under contract number DE-ACO2-76CHOOO16. Highest thanks go to Vincas P. Steponaitis, whose help and encouragement made this study possible. We also thank David W. Von Endt for the nitrogen analysis procedure. Others who gave their invaluable help include Dale L. Oxender, Christopher S. Peebles, Margaret J. Schoeninger, Paul D. Welch and C. Loring Brace.

\section{REFERENCES}

Garlick, J. D., 1969, in Science in Archaeology, second Edition (eds. Brothwell and Higgs) Thames and Hudson, Chap. 43.

Hagen, R., 1973, Calc. Tissue Research 13, 259.

Hoskins, C. R. and Fryd, C. F. M., 1955, J. Appl. Chem. 5, 85.

Mound State Monument Files, Alabama Museum of Natural History, The University of Alabama, Tuscaloosa; Peebles, C. S.. 1979, Excavations at Moundville, 1905-1951, microfiche, Univ. of Michigan Press, Ann Arbor.

Ortner, D. J., Von Endt, D. W. and Robinson, M. S., 1972, American Antiquity 37, 514.

Shroy, R. E., Kraner, H. W., Jones, K. W., Jacobson, J. S. and Heller, L. I., 1978, Nuclear Instruments and Methods 149, 313.

Steponaitis, V. P., 1978, Bull. Southeastern Archaeological Conf., no. 22.

Steponaitis, V. P., 1979, unpublished.

Taylor, R. E. 1975. World Archaeology 7, 127.

Tse, C., Welch, D. O. and Royce, B. S. H., 1973, Calc. Tissue Research 13, 47.

Underwood, E. J., 1977, Trace Elements in Human and Animal Nutrition, Fourth Edition, Academic Press.

Von Lndt, W., 1979, Pre-Llano Cultures of the Americas: Paradoxes and Possibilities, (eds. Humphrey and Stanford) The Anthropological Society of Washington, pp. 71-100.

Yule, G. U, and Kendall, M. G., 1965, An Introduction to the Theory of Statistics, Fourteenth Edition, Charles Griffin and Co., London. 